\title{
Power Relations Revealed by a Turn-taking Analysis in Major Barbara
}

\author{
Yan Liu \\ Lillian's Language Workshop, Room 107, the 22nd Building, Bailian Residential District, Number11 Panda Avenue, \\ Chengdu, Sichuan Province, China
}

\begin{abstract}
Major Barbara is a famous drama written by George Bernard Shaw. And turn-taking analysis is one of the methods developed within the relatively new field of drama stylistics. The present paper attempts to reveal power relations among the characters under a framework for quantitative turn-taking analysis. An excerpt from Major Barbara is examined. The study shows that the turn-taking analytic framework could achieve not only descriptive adequacy, but also explanatory adequacy to a certain extent.
\end{abstract}

Keywords: Turn-taking, Power relations, Major Barbara.

\section{Introduction}

Power relations among characters are associated firmly with the turn-taking in a drama. Though power has many different meanings, this paper will only discuss the social power. And turn-taking can embody such power relations incisively.

Turn-taking model is advocated by Harvey Sacks; Emanuel A. Schegolff and Gail Jefferson[1].This theory includes two parts: turn-taking constructional component and turn-taking allocation component. As a matter of fact, the meaning of turn-taking refers to the speaking right and duty given to a participant in the conversation as well as the utterances they have spoken. Opinions about the definition of turn-taking vary. For example, scholars disagree on whether body language and feedback belong to turn-taking. But in order to study more conveniently under the turn-taking analytic framework, this paper holds that any utterance is a turn-taking.

A framework for quantitative turn-taking analysis consists of five parts on the whole: (1) the initiation and control of topics; (2) turn length; (3) turn type; (4) interruption and monologue; (5) turn control strategies[2]. They will be introduced in the following part briefly.

(1) The initiation and control of topics

Topic is the real substance in the conversation. It is one of the important aspects in turn-taking construction to choose, bring in, develop and change the topic. A drama has a host of topics, and a fragment often has a topic. In the process of introducing, developing and changing the main topic, a series of relative topics will appear. Some scholars call it sub-topic(子话题)[2]. Other relative topics may be inserted in the sub-topic. As a result, sub-topic may be divided into different levels which can be described as first level sub-topic and second level sub-topic, and the rest may be deduced by analogy.

\section{(2) Turn length}

Because turn-taking length is in direct proportion to the number of words, so it is a more scientific and feasible method to count the turn-taking length by numbering words. This way is to be used in the present paper.

(3) Turn type

About turn type, it is can be divided into initiative turns, responsive turns, initiative turns after response and monologue (ibid.27).

It is not easy to judge which type the turn-taking is attached to. But there are two rules can be followed: one is according to factors such as time, place, interrelation and communication purposes in the co-text and context of turn-taking; the other is adopting "the co-reference and negotiation among different analyzers" (ibid.27).

\section{(4) Interruption and monologue}

According to turn-taking allocation rule, turn-taking usually occurs in the transition relevance place (TRP), namely the place where the turn-taking may stop, otherwise it is the purposeful interruption phenomenon.

\section{(5) Turn control strategies}

According to turn-taking allocation rule, turn control strategies can be divided into two groups: (a) those in which next turn is allocated by current speaker selecting next speaker; (b) those in which a next turn is allocated by self-selection (Sacks, Schegolff \&Jefferson, 1974: 703). Generally speaking, participants always hope to talk about their own topic to fulfill their communication purposes in the conversation. So this paper mainly studies the second kinds of turn control techniques which are distributed into five groups. In the addition to interruption and monologue mentioned above, there are still other three groups: (1) take advantage of pre-sequence to introduce the subject; (2) space-making strategies (限制话语长度的语用策略); (3) take advantage of paralinguistic features, such as expression, action, gesture and silence.

In the following parts, we will take a paragraph at the beginning of Major Barbara for example to illustrate the corresponding relation between the turn-taking and power. 


\section{Power Relations Revealed by a Turn-taking Analysis in Major Barbara}

The background of the act adopted from Major Barbara is like this: In January of 1906, it happened after dinner in Mrs. Britomart Undershaft's study which was well furnished. While Mrs. Britomart Undershaft was writing, her son Stephen was coming. Britomart was an arbitrary mother. Though Stephen was strong-willed, more or less he still held his mother in awe due to habits shaped in childhood and his shyness as a young man.
This fragment has 31 turn-takings. Among them, Mrs. Britomart Undershaft accounts for 17 while Stephen accounts for 15 turn-takings. This paper mainly studies the turn-taking between the two characters: Mrs. Britomart Undershaft and her son, Stephen. The analytic result can be seen in the following table1 (The fragment of the drama will be enclosed at the end of the paper).

In the fragment, there are three first sub-topics: one is that Mrs. Britomart Undershaft hopes Stephen should assume more household responsibilities; the other is about Stephen's father and the third one is about girls at home and Charles Lomax.

Table 1: The Analytic Result

\begin{tabular}{|c|c|c|c|c|c|c|c|c|c|}
\hline \multirow{2}{*}{\multicolumn{2}{|c|}{$\begin{array}{c}\text { The first sub-topic } \\
\text { Character }\end{array}$}} & \multicolumn{2}{|c|}{ Topic 1: responsibility } & \multicolumn{2}{|c|}{ Topic 2: father } & \multicolumn{2}{|c|}{$\begin{array}{l}\text { Topic 3: girls and Charles } \\
\text { Lomax }\end{array}$} & \multicolumn{2}{|c|}{ Total } \\
\hline & & mother & son & mother & son & mother & son & mother & son \\
\hline \multicolumn{2}{|c|}{ The number of turn-taking } & 12 & 11 & 1 & 2 & 3 & 2 & 16 & 15 \\
\hline \multicolumn{2}{|c|}{$\begin{array}{l}\text { 1.Situation bout the initiation } \\
\text { turns and topic control }\end{array}$} & $\begin{array}{c}\text { Control } \\
\text { topic all the } \\
\text { time }\end{array}$ & $\begin{array}{l}\text { Initiation } \\
\text { turn, but no } \\
\text { topic control } \\
\end{array}$ & $\begin{array}{l}\text { Control the } \\
\text { new topic } \\
\text { quickly } \\
\end{array}$ & $\begin{array}{c}\text { Try to } \\
\text { change the } \\
\text { topic } \\
\end{array}$ & $\begin{array}{l}\text { Step into } \\
\text { another } \\
\text { topic } \\
\end{array}$ & $\begin{array}{l}\text { Lose topic } \\
\text { control } \\
\text { gradually } \\
\end{array}$ & \multicolumn{2}{|c|}{$\begin{array}{l}\text { The topic almost controlled } \\
\text { by mother }\end{array}$} \\
\hline \multicolumn{2}{|c|}{$\begin{array}{l}\text { 2. Average length of } \\
\text { turn-taking(words) }\end{array}$} & 7.4 & 7.6 & 6 & 18 & 22.3 & 9.7 & 11.7 & 7.2 \\
\hline \multirow{5}{*}{ 3. Turn type } & $\begin{array}{l}\text { Initiation } \\
\text { turns }\end{array}$ & 5 & 1 & 1 & 0 & 0 & 0 & 6 & 1 \\
\hline & $\begin{array}{c}\text { Response } \\
\text { turns }\end{array}$ & 2 & 7 & 0 & 1 & 1 & 1 & 10 & 10 \\
\hline & $\begin{array}{l}\text { Initiative } \\
\text { turns after } \\
\text { response } \\
\end{array}$ & 4 & 2 & 0 & 1 & 2 & 1 & 6 & 4 \\
\hline & interruption & 3 & 0 & 0 & 0 & 0 & 0 & 3 & 0 \\
\hline & monologue & 0 & 0 & 0 & 0 & 0 & 0 & 0 & 0 \\
\hline \multicolumn{2}{|c|}{ 4.Interruption \& monologue } & 0 & 0 & 0 & 0 & 0 & 0 & 0 & 0 \\
\hline \multirow{3}{*}{$\begin{array}{c}\text { 5. Turn } \\
\text { control } \\
\text { strategies }\end{array}$} & $\begin{array}{l}\text { Pre-sequence } \\
\text { (time) }\end{array}$ & 5 & 2 & 0 & 1 & 1 & 0 & 6 & 3 \\
\hline & $\begin{array}{l}\text { Space-making } \\
\text { Strategies } \\
\text { (time) }\end{array}$ & 1 & 0 & 0 & 0 & 0 & 0 & 1 & 0 \\
\hline & $\begin{array}{l}\text { Paralinguistic } \\
\text { Features } \\
\text { (time) }\end{array}$ & 4 & 8 & 1 & 2 & 1 & 0 & 6 & 10 \\
\hline
\end{tabular}

\subsection{The Initiation and Control of Topics}

Initiation and control of topic refer to the questions such as who puts forward the topic, how the topic develops and who controls the topic.

Mrs. Britomart Undershaft puts forward the topic all the time while Stephen hardly has any new topic in this fragment. In turn-taking 11, she hints that she wants to talk something very formally. And in turn-taking 15 and 17, she suggests that her son should hold more responsibility. Most of the time Stephen only reacts to her mother submissively. In turn-taking 24, Stephen is on the verge of changing a new topic (his father). But before he speaks out, his mother has pointed it out in the next turn-taking. Then, the topic about girls at home and Charles Lomax is also advocated by Mrs. Britomart Undershaft. On the contrary, Stephen always wants to take exception to her mother's topics, but his mother always leads him by the nose. At last his mother tells him that he is wrong anyway which puts his utterances under his control firmly.

\subsection{Turn Length}

Turn length is concerned with things whose turn-taking is the longest and whose number of turn-takings is the most. From Table 1, we can see that Mrs. Britomart Undershaft's turn-taking is 2.5 times as long as Stephen's on average. On the face of it, Mrs. Britomart Undershaft controls the topic. The longest turn-taking of Stephen has 35 words while her mother's has 126 words (turn-taking 31). Except for turn-taking31, Mrs. Britomart Undershaft has many relative longer turn-takings, for example turn-taking 11,17, 19 and 29 while only has two shorter turn-takings (turn-taking2 and 4). And her shortest turn-taking is an order (Presently, Stephen.), but her longer turn-takings are used to ask Stephen to assist herself in the household responsibility and give her advice.

\subsection{Turn Type}

Turn type is composed of initiative turns and responsive turns. Even though Stephen speaks firstly, it cannot be an initiative turn. Considering his question (What's the matter?) and the sight that Mrs. Britomart Undershaft is at her desk writing, maybe it is that Mrs. Britomart Undershaf has sent after her son to come over to the settee. Therefore Stephen's question seems to be a response but not an initiation.

All passages considered, from the beginning to the end Mrs. Britomart Undershaf always initiates turn-takings while Stephen always only replies. And it is prevalent from turn-taking 15 to 19 in particular. Mrs. Britomart Undershaf brings forth a new topic in turn 15, and Stephen answers in 
turn-taking16. Then she denies his response in turn-taking 17 and initiates turn-taking once more. (Don't repeat my words, please: It is a most aggravating habit. You must learn to face life seriously...)

\subsection{Interruption and Monologue}

Interruption refers to that turn-taking occurs in the place where it is not supposed to be broken off. From the Table 1, it shows that Mrs. Britomart Undershaf cuts into Stephen's utterances several times. Stephen is interrupted in turn-taking4/5, 16/17 and 20/21. Though turn-taking24 is similar with the former discussed turn-takings on the surface, it is not interrupted by Mrs. Britomart Undershaf but is given up by Stephen himself.

\subsection{Turn Control Strategies}

In this fragment, Mrs. Britomart Undershaf contests the topic control several times:
Turn-taking2: She tells Stephen that he should not speak which throws him into silence.

Turn-taking7: She does not allow Stephen to make excuse which stops him from initiating turn-taking again.

Turn-taking5: In the beginning, she prevents Stephen from repeating her words which has decided what he should say and what he should not say. In the end she asks Stephen to give her some advice, as a result, it means some topics is allocated to Stephen.

Turn-taking23: She asks Stephen to interfere in, which is also a kind of topic allocation.

Apart from using pre-sequence and space-making strategies, paralinguistic features is also very popular in this fragment. Consider the following Table2:

Table 2: Paralinguistic Features Analysis

\begin{tabular}{|c|c|c|c|c|}
\hline & Mrs. Britomart Undershaf & Reason & Stephen & Reason \\
\hline \multirow{3}{*}{ Expression } & \multirow{3}{*}{$\begin{array}{l}\text { Turn-taking13: astonished; with } \\
\text { some remorse }\end{array}$} & \multirow{3}{*}{$\begin{array}{l}\text { Not pleased with his } \\
\text { son's response }\end{array}$} & Turn-taking15/16: amazed & $\begin{array}{l}\text { Not believe in his mother's } \\
\text { words and being tense }\end{array}$ \\
\hline & & & Turn-taking19/20: much perplexed & $\begin{array}{c}\text { Short of self-confidence and } \\
\text { being shy and nervous }\end{array}$ \\
\hline & & & Turn-taking23/24: troubled & $\begin{array}{l}\text { Being very shy and weak } \\
\text { before mother }\end{array}$ \\
\hline Totaling & \multicolumn{2}{|c|}{2 kinds of expression } & \multicolumn{2}{|c|}{3 kinds of expression } \\
\hline \multirow{8}{*}{ Action } & $\begin{array}{l}\text { Turn-taking5: She finishes her } \\
\text { writing; rises; and comes to the } \\
\text { settee }\end{array}$ & $\begin{array}{l}\text { Squeeze time to talk with } \\
\text { her son }\end{array}$ & $\begin{array}{c}\text { Turn-taking2/3: Stephen submissively } \\
\text { walks to the settee and sits down. He takes } \\
\text { up The Speaker }\end{array}$ & Hold mother in awe \\
\hline & \multirow{2}{*}{$\begin{array}{c}\text { Turn-taking7: He takes the cushion } \\
\text { from the chair at the desk and } \\
\text { arranges it for her as she sits down on } \\
\text { the settee }\end{array}$} & \multirow{2}{*}{$\begin{array}{l}\text { Go to the settee and } \\
\text { intend to say something } \\
\text { seriously }\end{array}$} & $\begin{array}{l}\text { Turn-taking 5: He puts down The } \\
\text { Speaker. }\end{array}$ & $\begin{array}{c}\text { Being subjected to his mother } \\
\text { easily. }\end{array}$ \\
\hline & & & \multirow{2}{*}{$\begin{array}{l}\text { Turn-taking7: } \\
\text { He takes the cushion from the chair at the } \\
\text { desk and arranges it for her as she sits } \\
\text { down on the settee. He sits down and } \\
\text { fingers his tie nervously. }\end{array}$} & \multirow{2}{*}{$\begin{array}{c}\text { Facing his mother, Stephen is } \\
\text { very shy and nervous. He is } \\
\text { very obedient to his bossy } \\
\text { mother. }\end{array}$} \\
\hline & \multirow{2}{*}{$\begin{array}{l}\text { Turn-taking15: squaring herself at } \\
\text { him rather aggressively }\end{array}$} & \multirow{2}{*}{$\begin{array}{l}\text { Dissatisfied with the } \\
\text { response and lead to topic }\end{array}$} & & \\
\hline & & & $\begin{array}{l}\text { Turn-taking8/9: He fiddles with his } \\
\text { watch chain instead. }\end{array}$ & $\begin{array}{l}\text { He do not dare to look his } \\
\text { mother in his eyes }\end{array}$ \\
\hline & \multirow{3}{*}{ Turn-taking28/29: complacently } & \multirow{3}{*}{$\begin{array}{l}\text { She holds that she deals } \\
\text { with the thing about girl } \\
\text { at home and Charles } \\
\text { Lomax very well }\end{array}$} & $\begin{array}{l}\text { Turn-taking11/12: hastily relinquishing } \\
\text { the chain }\end{array}$ & $\begin{array}{l}\text { Being weak before his } \\
\text { mother. He is afraid of } \\
\text { contradicting her. }\end{array}$ \\
\hline & & & Turn-taking24/25: He stops, ashamed & $\begin{array}{l}\text { He gives up to control the } \\
\text { topic. }\end{array}$ \\
\hline & & & Turn-taking25/26: almost inaudibly & $\begin{array}{l}\text { He loses the control of topic } \\
\text { gradually. }\end{array}$ \\
\hline Totaling & \multicolumn{2}{|c|}{5 kinds of action } & \multicolumn{2}{|c|}{11 kinds of action } \\
\hline
\end{tabular}

From Table 2 we can see that Stephen uses more paralinguistic features strategies in turn-takings than Mrs. Britomart Undershaf does. Those paralinguistic features in the turn-taking reveal that Britomart is an arbitrary mother and in spite of Stephen's strong-will, he more or less still holds his mother in awe due to habits shaped in childhood and his shyness as a young man.

\section{Conclusion}

The relationship between turn-taking and power of roles in Major Barbara is set out vividly and incisively by performing the analysis on the five parts mentioned above. The analytic process makes clear that the turn-taking analytic framework could achieve not only descriptive adequacy, but also explanatory adequacy to a certain extent.
Combined with co-text and context, this framework can reveal the power relations among the characters and delineate their temperament as well as uncover their ethic principle orientation and the law of plot development. To sum up, the framework for quantitative turn-taking analysis is a workable method for drama criticism on base of solid linguistics. In the past, literature criticism is inclined to be the critics' subjective sensation or qualitative speculation which is short of objective and quantitative argument. And the turn-taking analytic framework can redeem such deficiency to some extent.

\section{References}

[1] Jefferson G, Korbut A, Sacks H, et al. A simplest systematics for the organization of turn-taking for conversation[J]. Language, 1974, 50(4): 696-735. 
[2] Li Huadong, Yu Dongming. Power Relations, Character Depiction and Plot Development from the Turn of Turns[J]. Journal of the PLA Institute of Foreign Languages, 2001, 24(2): 26-30.

[3] GB Shaw, ET Forter. Major Barbara[J]. Penguin Books, 2001, 11(3): 227-244.

[4] Sacks H, Schegloff E A, Jef Fe Rson G. Chapter 1: A Simplest Systematics for the Organization of Turn Taking for Conversation[M]. Elsevier Inc, 1978.

[5] He Ziran. Pragmatics and English Learning [M]. Shanghai: Shanghai Foreign Language Education Press, 2003.

[6] Jiang Wangqi. Pragmatics-Theory and Application [M]. Beijing: Peking University Press, 2000.

[7] Li Huadong, Yu Dongming. A Quantitative Analysis Method of Word Rotation in Drama Stylistics[J]. Journal of Sichuan University of Foreign Languages, 2001, 17(3): 4.

[8] Liu Shisheng, Zhu Ruiqing. Introduction to Stylistics [M]. Peking University Press, 2006.

[9] Yang Xueyan. On the Status of Drama in Linguistics and Stylistics[J]. Foreign Languages, 1989(1): 4.

[10] Yang Xueyan. Discourse Analysis and Dramatic Linguistic Stylistics[J]. Foreign Language Teaching and Research, 1991(2): 6.

[11] Yu Dongming. Drama Stylistics and Drama Stylistics[J]. Journal of Zhejiang University: Humanities and Social Sciences, 1996(1): 4.

[12] ibid.27 